\title{
Juniper Tar
}

National Cancer Institute

\section{Source}

National Cancer Institute. Juniper Tar. NCI Thesaurus. Code C71827.

The tarry liquid obtained by distallation of the wood of Juniperus oxycedrus. Juniper tar is used as a topical treatment for various skin conditions. 